\title{
Direct rosiglitazone action on steroidogenesis and proinflammatory factor production in human granulosa-lutein cells Qiuju Chen ${ }^{\dagger 1}$, Xiaoxi Sun ${ }^{\dagger 2}$, Junling Chen ${ }^{3}$, Linan Cheng1, Jian Wang1, Yongwei Wang ${ }^{2}$ and Zhaogui Sun*1
}

\begin{abstract}
Address: ${ }^{1}$ NPFPC Key Laboratory of Contraceptives and Devices, Shanghai Institute of Planned Parenthood Research, Shanghai, PR China, 2Department of Reproductive Medicine, International Peace Maternity and Child Health Hospital, Shanghai JiaoTong University, Shanghai, PR China and ${ }^{3}$ Department of Obstetrics and Gynecology, Child and Family Research Institute, University of British Columbia, Vancouver, British Columbia, V6H 3V5, Canada

Email: Qiuju Chen - chenqiuju2865@hotmail.com; Xiaoxi Sun - xiaoxi_sun@hotmail.com; Junling Chen - chen_junling@hotmail.com; Linan Cheng - linanc2@yahoo.com; Jian Wang - wangjiansippr@126.com; Yongwei Wang - david_zl88@hotmail.com;

Zhaogui Sun* - sunzgbio@yahoo.cn

* Corresponding author †Equal contributors
\end{abstract}

Published: 9 December 2009

Reproductive Biology and Endocrinology 2009, 7:147 doi:10.1 186/1477-7827-7-147

This article is available from: http://www.rbej.com/content/7/I//47

(c) 2009 Chen et al; licensee BioMed Central Ltd.

This is an Open Access article distributed under the terms of the Creative Commons Attribution License (http://creativecommons.org/licenses/by/2.0), which permits unrestricted use, distribution, and reproduction in any medium, provided the original work is properly cited.
Received: 30 September 2009

Accepted: 9 December 2009

\begin{abstract}
Background: Ovarian granulosa cells are the predominant source of estradiol and progesterone biosynthesis in vivo. Rosiglitazone, a synthetic agonist of the peroxisome proliferator-activated receptor gamma (PPAR gamma), is applied as the treatment of insulin resistance including women with PCOS. The aim of the study was to investigate the direct effects of rosiglitazone on steroidogenesis and proinflammatory factor production in human granulosa-lutein cells (GLCs).
\end{abstract}

Methods: Primary human GLCs were separated during in vitro fertilization and cultured in the presence of rosiglitazone, GW9662 (an antagonist of PPAR gamma) and hCG. The mRNA expression of key steroidogenic factors including 3beta- hydroxysteriod dehydrogenase (3betaHSD), cytochrome P-450 scc (CYPIIAI), cytochrome P-450 aromatase (CYPI9AI), and steroidogenic acute regulatory protein (StAR) were detected by quantitative real-time PCR. Estradiol and progesterone levels in GLCs cultures were measured by chemiluminescence immunoassay, and the proinflammtory factors (TNFalpha and IL-6) in conditioned culture media were measured by ELISA.

Results: PPAR gamma mRNA levels increased up to 3.24 fold by rosiglitazone at the concentration of 30 microM compared to control $(P<0.05)$. hCG alone or hCG with rosiglitazone had no significant effects on PPAR gamma mRNA levels. The CYPI9AI mRNA level at exposure to rosiglitazone alone showed a drop, but was not significantly reduced comparing to control. The expression levels of enzymes 3beta-HSD and CYPIIAI in all treatments did not alter significantly. The StAR mRNA expression at exposure to rosiglitazone was significantly increased comparing to control $(P<0.05)$. The media concentrations of $E 2$ and progesterone by rosiglitazone treatment showed a declining trend comparing to control or cotreatment with hCG, which did not reach significance. Most importantly, treatment with rosiglitazone decreased TNFalpha secretion in a statistically significant manner compared with control $(P<0.05)$. The concentration of IL-6 following rosiglitazone exposure did not significantly decrease comparing to control. 
Conclusion: In cultured GLCs, rosiglitazone stimulated StAR expression, but did not significantly affect steroidogenic enzymes, as well as E2 and progesterone production. Moreover, rosiglitazone significantly decreased the production of TNFalpha in human GLCs, suggesting that PPAR gamma may play a role in the regulation of GLCs functions through inhibiting proinflammatory factors.

\section{Background}

Peroxisome proliferator-activated receptor $\gamma$ (PPAR $\gamma)$, a well-studied member of the nuclear receptor superfamily, has been implicated in numerous biological processes, including adipocyte differentiation, regulation of lipid and glucose homeostasis, and control of inflammatory responses [1-3]. PPAR $\gamma$ represents important targets for obesity, obesity-induced inflammation, and metabolic syndrome in general. PPAR $\gamma$ agonist, thiazolidinedione (TZD, including troglitazone, rosiglitazone and pigolitazone), is currently used to treat type diabetes (NIDDM) and also to attenuate the secondary clinical symptoms frequently associated with insulin resistance including polycystic ovary syndrome (PCOS) [1-4]. Given that troglitazone has been withdrawn from the market because of hepatotoxicity and one of the important current available PPAR agonists, rosiglitazone, has a binding affinity for PPAR $\gamma$ 100-fold greater than that of troglitazone [3].

In the ovary, PPAR $\gamma$ is expressed most strongly in granulosa cells, and less strongly in theca cells and corpora lutea [5]. The PPAR $\gamma$ is involved in varied processes such as steroidogenesis, angiogenesis, tissue remodeling, cell cycle, apoptosis, and lipid metabolism, which are critical for normal ovarian function. Recently, using the mouse mutant model, granulosa cell-specific deletion of PPAR $\gamma$ resulted in marked impairment of ovulation owing to defective follicular rupture and thereby discovered a critical ovarian function of this factor [5]. Rosiglitazone can directly influence ovarian function and ultimately exert positive effects on oocyte developmental competence in mice [6]. Improved blastocyst quality in obese female mice treated with rosiglitazone before mating indicated that PPAR $\gamma$ was a key target for metabolic regulation of ovarian function and oocyte quality [7].

In recent reports, administration of TZD to women with PCOS resulted in a marked attenuation of hyperinsulinemia that was associated with improvements in insulin secretion, ovarian androgen biosynthesis, and enhanced fibrinolytic system capacity [1,3]. Although it is thought that the inhibitory effects of rosiglitazone on ovarian androgen production are a result of the reduction of circulating insulin levels induced by rosiglitazone, in several in vitro and in vivo studies in animal and human ovarian cells, PPAR $\gamma$ agonists have been reported to directly inhibit or increase activity of ovarian steroidogenic enzymes, progesterone and estradiol $\left(\mathrm{E}_{2}\right)$ production [8-
12]. To clarify the underlying mechanisms, experiments with isolated granulosa cells culture derived from normal women without endocrinological diseases are necessary. Granulose-lutein cells (GLCs) isolated from follicular fluid in in vitro fertilization- embryo transfer (IVF-ET) provides us a good source of experiment material.

PPAR $\gamma$ ligands including rosiglitazone also inhibit the activation of inflammatory genes expression and can negatively interfere with pro-inflammatory transcription factor signaling pathways in vascular and inflammatory cells [13]. PPAR $\gamma$ was demonstrated to control a unique network of downstream genes, including those encoding for interleukin-6 (IL-6) and tumor necrosis factor- $\alpha$ (TNF $\alpha$ ) [13-15]. Because these cytokines have indispensable effects in ovulation and luteinization $[16,17]$, it is important to understand the regulation of them by PPAR $\gamma$ in the preovulatory granulosa cells, which may be of considerable clinical significance during long-term therapy.

The objectives of this study were to determine the effects of PPAR $\gamma$ agonist rosiglitazone on steroidogenesis and proinflammtory factors production (TNFo and IL-6) in cultured GLCs from infertile women due to tubal blockage.

\section{Methods Subjects}

This study was approved by the Institutional Ethics Committee of Shanghai Institute of Planned Parenthood Research. All participants provided their informed consent before inclusion in this study. A total of 20 infertile women with tubal blockage undergoing controlled ovarian hyperstimulation $(\mathrm{COH})$ for in vitro fertilizationembryo transfer were enrolled into the study. All of the women had regular menstrual cycles and no evidence of PCOS or other endocrinopathies.

Ovarian stimulation protocols were carried out following our clinical routine described previously [18]. Briefly, Patients in $\mathrm{COH}$ cycles received a long stimulation protocol with GnRH agonist and recombinant FSH treatment. The GnRH-a ( $1.5 \mathrm{mg}$ ) was commenced on cycle day 21 of the preceding luteal phase. The starting gonadotropin dose was $150 \mathrm{IU} /$ day, with the dose being adjusted in an individual fashion after 6 days of ovarian stimulation. Ten thousand units of hCG were given IM when the leading follicle reached $18 \mathrm{~mm}$ and at least three follicles were 
$>15 \mathrm{~mm}$ in diameter. Transvaginal ultrasound-guided oocyte retrieval was scheduled 33-36 hours after the hCG injection.

\section{Follicle fluid collection and GLCs culture}

After oocyte retrieval, the follicular-aspirates containing GLCs from 3-4 patients were pooled for GLCs culture. Follicular aspirates were transported on ice to the laboratory and centrifuged at $1000 \mathrm{rpm}$ for $5 \mathrm{~min}$. The pellet was resuspended in PBS (Sigma Chemical Co., St. Louis, MO). The GLCs were separated from the blood cells and cellular debris using $50 \%$ percoll gradient centrifugation (Sigma) for 20 minutes. After centrifugation, the interphase cells were collected, washed with PBS by centrifugation for 5 minutes, and incubated with $0.1 \mathrm{mg} / \mathrm{mL}$ hyaluronidase (Sigma) for 5-10 minutes in DMEM/F12. The dispersed GLCs were centrifugated, washed and suspended in DMEM/F12 containing 10\% FBS, $100 \mathrm{U} / \mathrm{ml}$ penicillin, 0.1 $\mathrm{mg} / \mathrm{ml}$ streptomycin. The GLCs were seeded in a flask. Approximately $1 \times 10^{6}$ to $10 \times 10^{6}$ cells were obtained from each patient. Cellular viability was assessed by $0.4 \%$ Trypan blue exclusion test and ranged at 70-90\%.

After 48 hours, the cells were washed to remove remaining red blood cells which did not adhere to the plastic surface. The cells were then incubated for $24-72$ hours at $37^{\circ} \mathrm{C}$ in DMEM/F12 containing 10\% FBS in a humidified atmosphere with $5 \% \mathrm{CO}_{2}$ in air with following treatments: (1) basic media with $0.01 \%$ dimethylsulfoxide (DMSO); (2) different dose of rosiglitazone $(7.5 \mu \mathrm{M}, 15 \mu \mathrm{M}, 30 \mu \mathrm{M}, 60$ $\mu \mathrm{M})$ and rosiglitazone $30 \mu \mathrm{M}$ at different time $(24 \mathrm{~h}, 48 \mathrm{~h}$ and $72 \mathrm{~h}$ ); (3) PPAR $\gamma$ antagonist GW9662 at the concentration of $1 \mu \mathrm{M}$; (4) rosiglitazone at the concentration of $30 \mu \mathrm{M}$ and GW9662 at the concentration of $1 \mu \mathrm{M}$; (5) hCG at the concentration of $1 \mathrm{IU} / \mathrm{mL} ;(6)$ rosiglitazone at the concentration of $30 \mu \mathrm{M}$ and hCG at the concentration of $1 \mathrm{IU} / \mathrm{mL}$. At the same time, $0.1 \mu \mathrm{M}$ androstenedione was added to the cultures as substrate for estrogen production. Finally, the conditioned culture media were collected for ELISA and chemiluminent assay. The cultured GLCs were then removed from the dishes by a 5-minute treatment at $37^{\circ} \mathrm{C}$ with $0.25 \%$ trypsin. The cells were collected by centrifugation and stored at $-80^{\circ} \mathrm{C}$. All the treatments were repeated 6 times.

\section{RNA extraction, $R T$ reaction and real-time PCR}

Total RNA was extracted from GLCs using TRIzol (Invitrogen, Karlsruhe, Germany). Two micrograms of total RNA were reverse transcribed into cDNA. Twenty microliters of RT reaction mixture were used for RT -PCR. Forty nanograms of RNA, $2 \mu$ l of RT buffer, 10 IU of RNase Inhibitor, $2 \mu \mathrm{l}$ of oligo $(\mathrm{dT})(10 \mu \mathrm{M}), 2 \mu \mathrm{l}$ of dNTP-mix $(2.5 \mathrm{mM})$ and diethylpyrocarbonate (DEPC)-treated water up to 10 $\mu \mathrm{l}$ were mixed and incubated at $70^{\circ} \mathrm{C}$ for $5 \mathrm{~min}$ and then immediately placed on ice. Next, 50 IU of Superscript II Reverse Transcriptase was added. cDNA synthesis was carried out at $37^{\circ} \mathrm{C}$ for $60 \mathrm{~min}$. The reaction was stopped by incubating at $72^{\circ} \mathrm{C}$ for $10 \mathrm{~min}$. The samples were then stored at $-20^{\circ} \mathrm{C}$ until real-time PCR was performed.

Real-time PCRs were performed using Biorad Chromo4 real-time PCR detector (Bio-rad Co, CA, USA). The reaction mixture consisted of $200 \mathrm{nM}$ of each primer for targeted genes, $12.5 \mu \mathrm{l}$ SYB green PCR master mix and $9.5 \mu \mathrm{l}$ of the DEPC water, corresponding to a $0.5 \mathrm{ng}$ mRNA in a total reaction volume of $25 \mu \mathrm{l}$. The cDNA was denatured at $95^{\circ} \mathrm{C}$ for $1 \mathrm{~min}$. The template was then amplified over 36 cycles of $15 \mathrm{~s}$ of melting at $95^{\circ} \mathrm{C}, 15 \mathrm{~s}$ at $60^{\circ} \mathrm{C}$ for annealing and $45 \mathrm{~s}$ at $70^{\circ} \mathrm{C}$ for extension. The threshold cycle $(\mathrm{Ct})$ values were normalized to $\beta$-actin levels. Relative mRNA levels were calculated using the $2^{-\Delta \Delta C t}$ method. Primer sequences and the size of the expected PCR products for PPAR $\gamma$ and key steroidogenesis factors including

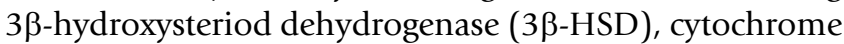
P-450 scc (CYP11A1), cytochrome P-450 aromatase (CYP19A1), and steroidogenic acute regulatory protein (StAR), as well as the endogenous control gene $\beta$-actin are presented in Table 1 . The specificity of the primers used in the study was confirmed by agarose gel electrophoresis and sequence analysis on the reaction products.

\section{Hormone measurements}

Concentrations of $\mathrm{E}_{2}$ and progesterone in the culture fluid were determined by chemiluminescence immunoassay using commercial kits obtained from Roche Diagnostics GmbH (Mannheim, Germany). The supernatant was diluted with the Assay Diluent (Roche Diagnostics $\mathrm{GmbH}$ ) by 50-200 folds when the sample generated value greater than the highest standard. Practical detection limits, within- and between assay coefficients of variation

Table I: Primer pairs used for PCR amplification

\begin{tabular}{lllll}
\hline Gene & Genebank access no. & Fragment length (bp) & Forward primer sequence & Reverse primer sequence \\
\hline PPAR $\gamma$ & NM 005037.5 & 161 & GAGCCCAAGTTTGAGTTTGC & CTGTGAGGACTCAGGGTGGT \\
$3 \beta-H S D$ & NM 000198.2 & 196 & GCCTGTTGGTGGAAGAGAAG & ATGATACAGGCGGTGTGGAT \\
CYPIIAI & NM 00078I.2 & 200 & GGAAATTACTCGGGGGACAT & AACAGACGGAACAGGTCTGG \\
StAR & NM 000349.2 & 157 & TACGTGGCTACTCAGCATCG & ACAGCAGGCTGGTCTTCAAC \\
CYPI9AI & NM 031226.2 & 242 & CAGAGGCCAAGAGTTTGAGG & ACACTAGCAGGTGGGTTTGG \\
$\beta$-actin & NM 00II0I.3 & 271 & CTACAATGAGCTGCGTGTGGC & CAGGTCCAGACGCAGGATGGC
\end{tabular}


were $18.4 \mathrm{pmol} / \mathrm{l}, 5.4 \%$ and $10.5 \%$, respectively, for $\mathrm{E}_{2}$ and $0.095 \mathrm{nmol} / \mathrm{l}, 6.2 \%$ and $9.5 \%$, respectively, for progesterone.

\section{Measurement of TNF and IL-6}

TNF $\alpha$ and IL- 6 concentration in culture media were determined using human ELISA kit (R\&D systems, Minneapolis, MN). The lower limits of detectability of TNF $\alpha$ and IL6 were $12 \mathrm{pg} / \mathrm{ml}$ and $10 \mathrm{pg} / \mathrm{ml}$, respectively. All measurements were carried out in duplicate. The intra- and interassay coefficients of variation for $\mathrm{TNF} \alpha$ were $8.5 \%$ and $10.3 \%$. The intra- and interassay coefficients of variation for IL-6 were less than $7.6 \%$ and $10 \%$, respectively.

\section{Statistical analysis}

SPSS 11.5 was used for the data analysis. A one-way ANOVA was used to estimate the statistical difference between the treatment groups. Turkey test was used for variables with normal distribution and the Dunnett's T3 test was used for variables with skewed distribution. A value of $P<0.05$ was considered significant.

\section{Results \\ Effects of rosiglitazone, GW9662 and hCG on PPAR expression}

The effect of rosiglitazone in different doses and time course on PPAR $\gamma$ expression in the GLCs is shown in Figure 1. PPAR $\gamma$ expression was stimulated by rosiglitazone which reached a peak point at the dose of $30 \mu \mathrm{M}(3.24$ fold compared to a DMSO control, $P<0.05)$. The mRNA expression of PPAR $\gamma$ was increased by rosiglitazone and no difference was found among three time points $(24 \mathrm{~h}$, $48 \mathrm{~h}$ and $72 \mathrm{~h}$ ). In the subsequent experiments, the duration of incubation was standardized to $72 \mathrm{~h}$ and the dose
A
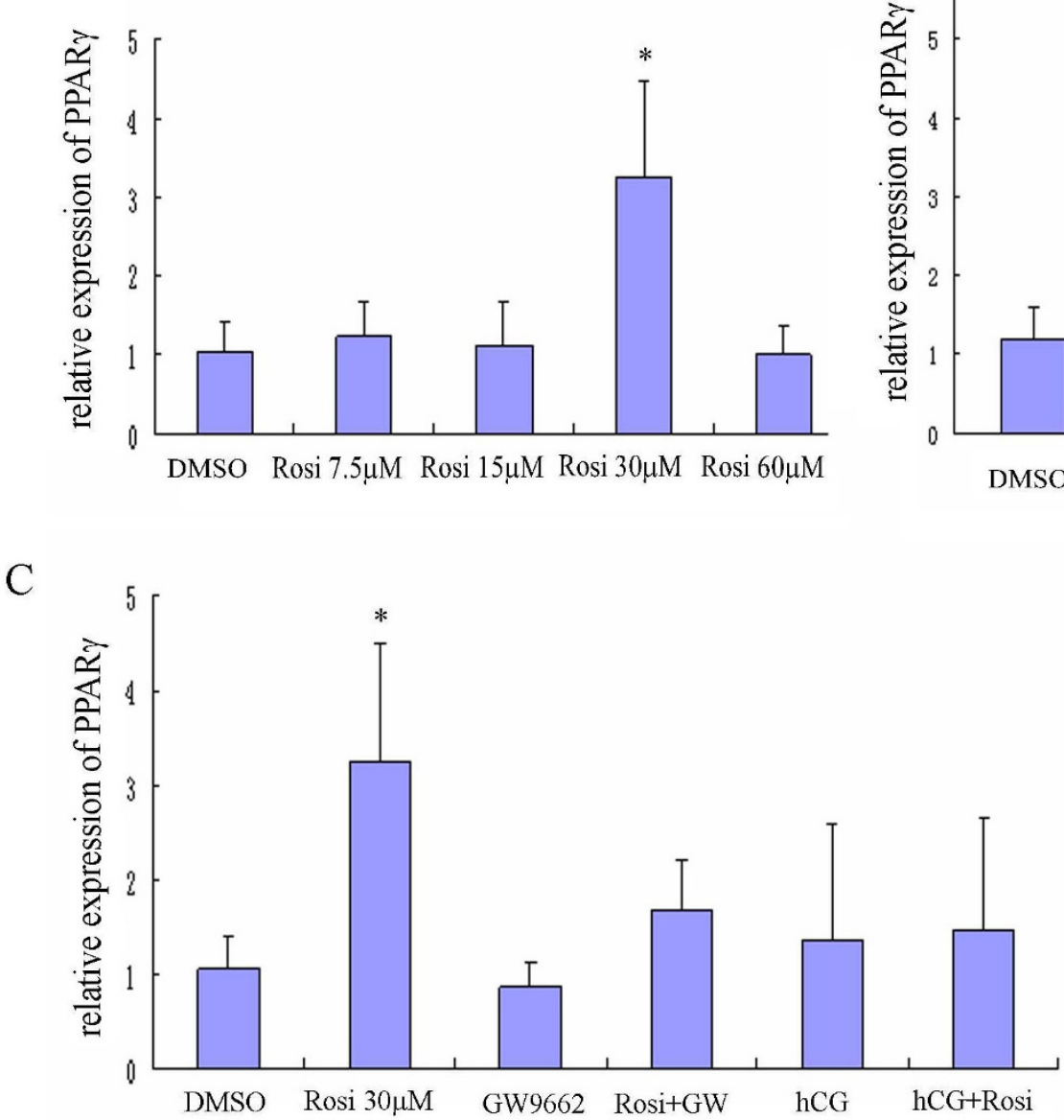

\section{Figure I}

Effects of rosiglitazone on PPAR $\gamma$ mRNA level in cultured GLCs. A. Relative expression of PPAR $\gamma$ after rosiglitazone (Rosi) treatment for $72 \mathrm{~h}$ in different doses. B. Time course of rosiglitazone on PPAR $\gamma$ mRNA level in cultured GLCs. C. Relative expression of PPAR $\gamma$ in cultured GLCs in response to rosiglitazone treatment for $72 \mathrm{~h}$ in the presence or absence of GW9662 and hCG. Results are expressed in ratio to $\beta$-actin, and presented as means \pm SD of six independent experiments. Statistical significances compared to the DMSO control are shown with one asterisk $(P<0.05)$. 
of rosiglitazone was $30 \mu \mathrm{M}$. When the cells were cotreated with GW9662, it partly reversed the effects of rosiglitazone in terms of PPAR $\gamma$ production but no significant difference was achieved. In addition, no significant effects on PPAR $\gamma$ production were shown after treatment with hCG alone or hCG together with rosiglitazone.

\section{Effects of rosiglitazone, GW9662 and hCG on steroidogenesis}

The mRNAs expression of key steroidogenic factors (CYP19A1, CYP11A1, 3 $\beta$-HSD and StAR) in GLCs are shown in Figure 2. The CYP19A1 mRNA expression following exposure to rosiglitazone showed a reducing trend but no significance was achieved comparing to the DMSO control. Cotreatment with hCG did not change CYP19A1 mRNA levels. The expression of $3 \beta$-HSD and CYP11A1 involved in progesterone synthesis did not alter at exposure to rosiglitazone, comparing to control or cotreatment with GW9662 and hCG. On the other hand, the StAR mRNA expression at exposure to rosiglitazone was dramatically increased compared with the DMSO control $(P$ $<0.05)$, and this was attenuated by hCG and GW9662.
The levels of $E_{2}$ and progesterone from the supernatant of GLCs cultures in the presence or absence of rosiglitazone, GW9662 and hCG for 72 hours were also examined (Figure 3 ). Rosiglitazone alone did not decrease $\mathrm{E}_{2}$ and progesterone levels compared with the control. In the presence of GW9662, $\mathrm{E}_{2}$ and progesterone levels in the exposure to rosiglitazone also showed no change compared with the control group $(P>0.05)$. Likewise, cotreatment with hCG demonstrated a decreasing trend on $\mathrm{E}_{2}$ and progesterone production, but did not achieve a significant difference.

\section{Effects of rosiglitazone, GW9662 and hCG on TNF and IL- 6 secretion}

Secretion of TNF $\alpha$ and IL- 6 by cultured GLCs in different treatments is shown in Figure 4 . Treatment with rosiglitazone alone or with the presence of GW9662 decreased TNF $\alpha$ secretion in a statistically significant manner compared with a DMSO control $(P<0.05)$. No significant difference was observed with hCG exposure alone, or together with rosiglitazone.
I Relative expression of CIP19h1

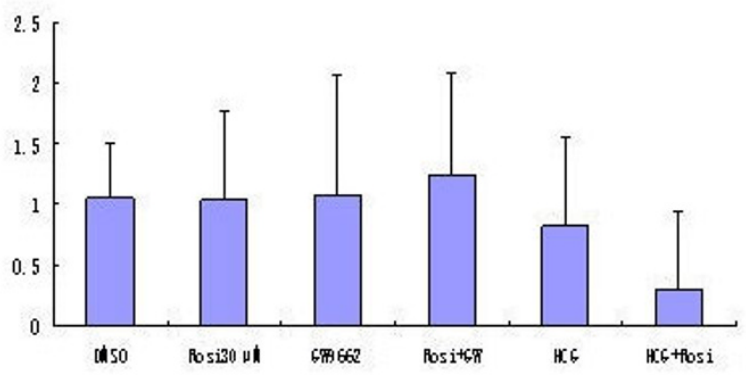

C Relative expression of CYP11M1

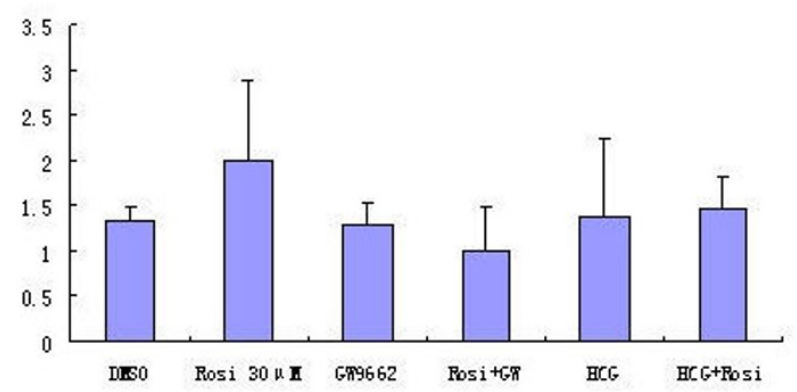

B Relative expression of 3beta-HSD

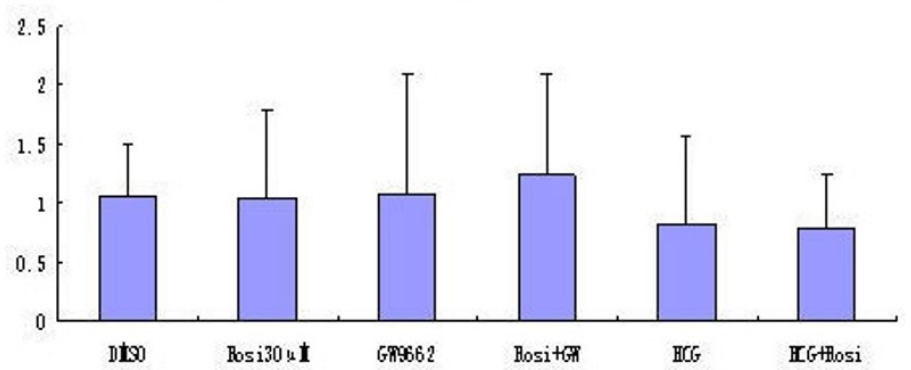

D Relative expression of StAR

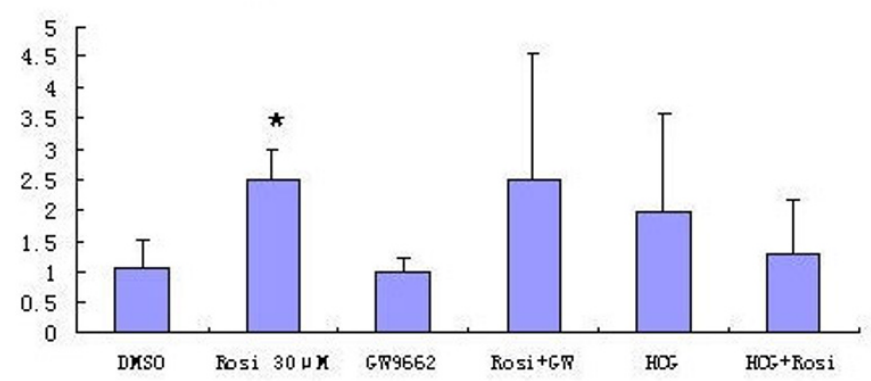

Figure 2

Regulation of steroidogenic factors by rosiglitazone, GW9662 and hCG in cultured GLCs. The granulosa cells were treated with rosiglitazone alone, or together with GW9662 and hCG for $72 \mathrm{~h}$. The relative expressions of CYPI9AI (A), $3 \beta$-HSD (B), CYPIIAI (C), StAR (D) were measured by real-time RT-PCR. Results in folds of $\beta$-actin are expressed as means \pm SD of six independent experiments. Statistical significances compared to the DMSO control are shown with one asterisk $(P$ $<0.05)$. 
A

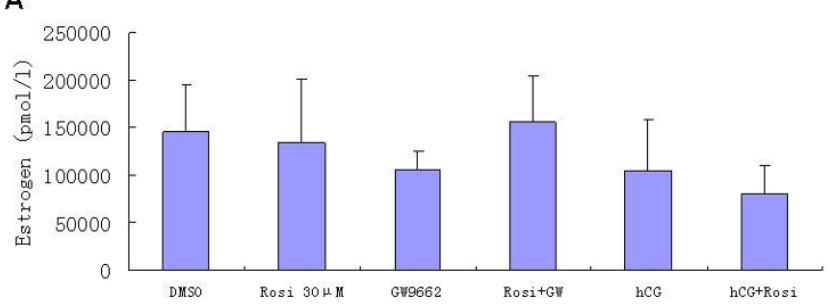

B

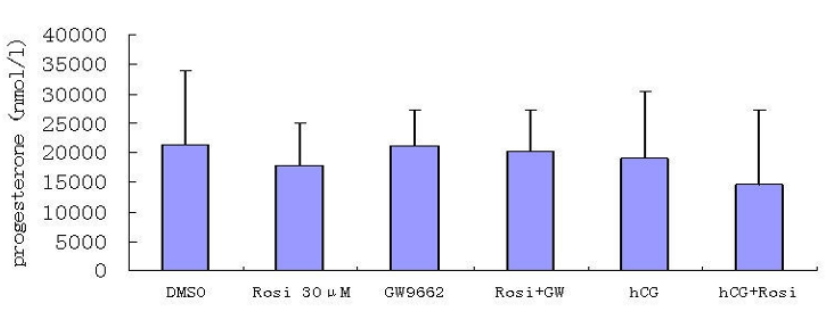

Figure 3

Effects of rosiglitazone, GW9662 and hCG on steroid hormone production in cultured GLCs. Concentrations of $E_{2}(A)$ and progesterone (B) in the culture fluid of GLCs treated with or without rosiglitazone, GW9662 and hCG for $72 \mathrm{~h}$. Values are means \pm SD of six independent experiments.

Rosiglitazone decreased IL-6 secretion, whereas did not reach statistical significance. With the presence of GW9662 or hCG, similarly, IL-6 did not change significantly.

\section{Discussion}

In order to explore the possible direct effects of rosiglitazone on human GLCs, we have investigated the production of steroid hormones and proinflammatory factors in GLCs in in vitro culture exposure to PPAR $\gamma$ agonist and antagonist. The results indicated that rosiglitazone significantly stimulated StAR mRNA expression, but did not affect steroidogenic enzymes, neither $\mathrm{E}_{2}$ nor progesterone production. More interestingly, rosiglitazone significantly decreased TNFa levels in GLCs. Thus, PPAR $\gamma$ may play a role in the regulation of GLCs functions through inhibiting proinflammatory factors.

Despite that in vitro studies may not necessarily reflect normal physiology in vivo, in vitro experiments may be vital to increase our knowledge of the way in which rosiglitazone influences the function of GLCs. Our data explicated that PPAR $\gamma$ expression was stimulated by rosiglitazone and the greatest response was observed at the concentration of $30 \mu \mathrm{M}$. The time course was found no difference among the incubation time 24-72 h. Therefore rosiglitazone $30 \mu \mathrm{M}$ at $72 \mathrm{~h}$ incubation was used for our further experiments and was also approximately comparable to the reports $[8,19]$. The widely-used selective PPAR antagonist, GW9662, partially reversed the effects of rosiglitazone in terms of PPAR $\gamma$ production, though not significantly. It has been reported that GW9662 could regulate cell growth at high dosages independent of PPAR $\gamma$ $[20,21]$ and this may be the reason for not completely reversing the effect of rosiglitazone.

In nonreproductive tissues, PPAR $\gamma$ has been shown to have a variety of actions within resident macrophage immune cells such as regulating cytokine mRNA expression to modulate overall inflammatory response [15]. TZD activation of PPAR $\gamma$ affect monocyte/macrophage function by downregulating transcription of proinflammatory genes such as inducible nitric oxidase synthase $\left(\mathrm{NOS}_{2}\right), \mathrm{IL}-1 \beta$, IL-6, IL-12 and TNF $\alpha[14,15,22,23]$. The present study showed for the first time that TNF $\alpha$ was significantly suppressed by rosiglitazone in cultured GLCs. Whereas IL-6 secretion after rosiglitazone treatment appeared to decrease, although this did not achieve significance. TNF $\alpha$ is a multifunctional hormone-like polypeptide and modulates many genes involved in inflammation, infection, and malignancy [17]. Although macrophages are a main source of TNFa, GLCs and corpora lutea have been reported to contain TNFa [24]. $\mathrm{TNF} \alpha$ is well known in regulating steroidogenesis, ovulation and luteinization in numerous species including rodents and humans [25-27]. PPAR $\gamma$ played a major role in ovulation because conditional loss of the PPAR $\gamma$ gene in GLCs did not affect ovarian follicular development but prevent follicular rupture [5]. It was supposed that PPAR $\gamma$ may be involved in ovulation and luteinization by inhibiting the secretion of TNF $\alpha$ in GLCs in the present study. The detail mechanism remains unclear and needs further study.

Steroidogenic acute regulatory protein (StAR) plays an essential role in cholesterol transfer from the outer to the inner mitochondrial membrane, thus providing the substrate for steroid hormone biosynthesis [9-11]. Cholesterol is then converted to pregnenolone by the CY11A1 enzyme, initiating steroid biosynthesis. In the present study, rosiglitazone stimulated the StAR mRNA up to 2.6 fold, the results suggested that activation of steroid hormone synthesis by rosiglitazone may be mediated via activation of StAR. In the previous report, the insulin or TZDs up-regulated PPAR $\gamma$, insulin receptor, insulin receptor substrate-1 and StAR protein expression, so it were presumed that PPAR $\gamma$, StAR protein and insulin receptor constituted a novel system of ovarian regulation [19].

The steroid hormone production is a multi-step process, requiring action of multiple enzymes. In the present study, the changes of key steroidogenic enzymes (CYP19A1, CYP11A1 and 3 $\beta$-HSD) induced by rosiglitazone were not obvious in the GLCs. Moreover, the nonsignificant results for rosiglitazone affecting concentra- 

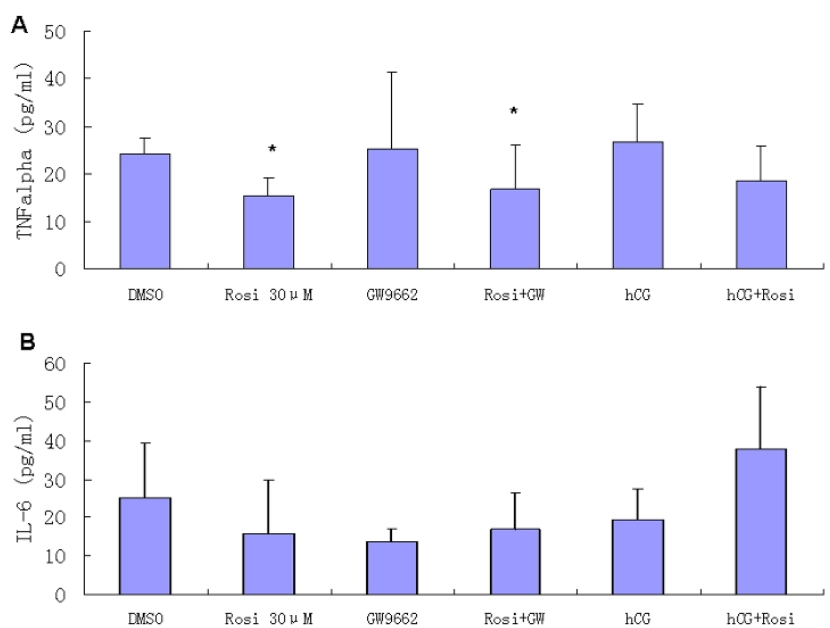

Figure 4

Effects of rosiglitazone, GW9662 and hCG on TNF $\alpha$ and IL-6 secretion in cultured GLCs. Concentrations of TNF $\alpha(A)$ and IL-6 (B) in the culture fluid of GLCs treated with or without rosiglitazone, GW9662 and hCG for $72 \mathrm{~h}$. Values are means \pm SD of six independent experiments. Asterisk $(*)$ denotes significant differences comparing to the DMSO control $(P<0.05)$.

tions of $E_{2}$ and progesterone were coincident with the aboved changes of steroidogenic enzymes. So in the present study, although PPAR $\gamma$ stimulated StAR mRNA expression, the activation of PPAR $\gamma$ did not play a major role in the regulation of steriod hormone production in the cultured GLCs.

In the present study, the effects of rosiglitazone on steroidogenesis were different from some previous reports. Rosiglitazone directly stimulated progesterone and IGFBP-1 production, while inhibited $\mathrm{E}_{2}$ and testosterone production using a culture system of mixed ovarian cells [8]. Troglitazone suppressed progesterone production specially by inhibiting the activity of $3 \beta$-HSD in porcine granulosa cells $[9,11]$. In our study, the GLCs isolated from follicular fluid in IVF-ET was in the final stage of differentiation, the responses to rosiglitazone were possibly different from the cells obtained from oophorectomy specimens in human and porcine.

In contrast with the previous report that hCG stimulation induced a transcriptional burst of genes involved in progesterone synthesis ( $3 \beta-\mathrm{HSD}, \mathrm{CYP} 11 \mathrm{~A} 1$ and StAR) using luteinized granulosa cells [28], no significant changes were found regarding key steroidogenic enzymes and proinflammatory factors when adding hCG to the GLCs. The fact could not be ignored that the GLCs obtained from IVF patients at the time of oocyte retrieval have received superphysiological doses of gonadotrophins before they were put into culture. The GLCs may have gonadotrophin desensitization due to their over exposition to FSH and LH treatment in vivo so they can not obtain marked response by adding another gonadotrophin stimulant. Similar results were reported in the previous studies [29-31].

In order to determine the action of PPAR $\gamma$ on steroidogenesis in GLCs, more convincing data could be obtained by knocking down of PPAR $\gamma$ expression using human PPAR $\gamma$ siRNA in cultured GLCs. Given that primary GLCs are difficult to transfer using siRNA, the immortalized granulosa cell lines will be good candidate for studying the regulation mechanism of PPAR $\gamma$.

\section{Conclusion}

In summary, although rosiglitazone stimulated StAR expression in human GLCs, the results demonstrated that rosiglitazone did not significantly inhibit $\mathrm{E}_{2}$ and progesterone productions in cultured GLCs, Moreover, rosiglitazone significantly decreased the production of TNF $\alpha$ in human GLCs, suggesting that PPAR $\gamma$ may play a role in the regulation of GLCs functions through inhibiting proinflammatory factors. Further studies need to investigate the molecular regulating mechanism of PPAR $\gamma$ on the GLCs. Careful attention also needs to be paid to the possibility that long-term treatment with rosiglitazone in patients with NIDDM and PCOS might also cause unexpected side effects, such as ovarian dysfunction.

\section{Competing interests}

The authors declare that they have no competing interests.

\section{Authors' contributions}

CQ performed most of the experiments, contributed to analysis and interpretation of the data and drafting of the manuscript. SX contributed to the study planning and interpretation of the data and revision of the manuscript. CJ contributed to the study planning and revised it critically for intellectual content. WJ and CL participated in the study design and revision of the manuscript. WY provided human GCs and performed a part of the experiments. SZ designed the study and contributed to interpretation of the data and writing of the manuscript. All authors read and approved the final manuscript.

\section{Acknowledgements}

We would like to thank Professor Peter C K Leung of the Department of Obstetrics and Gynecology of University of British Columbia for his helpful advice. We acknowledge the help of the staff and patients of the Department of Reproductive Medicine in International Peace Maternity and Child Health Hospital for provision of granulosa cells. The research was funded by the Shanghai Scientific Technology Council (No.08ZRI4I6500) and the National Basic Research Program of China (Project No. 2006CB504005). 


\section{References}

I. Forment $P$, Touraine $P$ : Thiazolidinediones and fertility in polycystic ovary syndrome (PCOS). PPAR Res 2006, 2006:73986.

2. Yki-Jarvinen H: Thiazolidinediones. New Engl J Med 2004, 35 I: II06-III8.

3. Pasquali R, Gambineri A: Insulin-sensitizing agents in polycystic ovary syndrome. Eur J Endocrinol 2006, I 54:763-775.

4. Froment P, Gizard F, Defever D, Staels B, Dupont J, Monget P: Peroxisome proliferator-activated receptors in reproductive tissues: from gametogenesis to parturition. J Endocrinol 2006, I 89:199-209.

5. Komar CM: Peroxisome proliferator-activated receptors (PPARs) and ovarian function--implications for regulating steroidogenesis, differentiation, and tissue remodeling. Reprod Biol Endocrinol 2005, 3:4I.

6. Kim J, Sato M, Li Q, Lydon JP, Demayo FJ, Bagchi IC, Bagchi MK: Peroxisome proliferator-activated receptor gamma is a target of progesterone regulation in the preovulatory follicles and controls ovulation in mice. Mol Cell Biol 2008, 28: I770-I 782.

7. Minge CE, Bennett BD, Norman RJ, Robker RL: Peroxisome proliferator-activated receptor- $\gamma$ agonist rosiglitazone reverses the adverse effects of diet-induced obesity on oocyte quality. Endocrinology 2008, I49:2646-2656.

8. Seto-Young D, Paliou M, Schlosser J, Avtanski D, Park A, Patel P, Holcomb K, Chang P, Poretsky L: Direct thiazolidinedione action in the human ovary: insulin-independent and insulin-sensitizing effects on steroidogenesis and insulin-like growth factor binding protein-I production. J Clin Endocrinol Metab 2005, 90:6099-6105.

9. Gasic S, Nagamani M, Green A, Urban RJ: Troglitazone is a completive inhibitor of 3- $\beta$-hydroxysteroid dehydrogenase enzyme in the ovary. Am J Obstet Gynecol 200I, I 84:575-579.

10. Mu Y, Yanase T, Nishi Y, Waseda N, Oda T, Tanaka A, Takayanagi R, Nawata $\mathrm{H}$ : Insulin sensitizer, troglitazone directly inhibits aromatase activity in human ovarian granulosa cells. Biochem Biophys Res Commun 2000, 27 I:710-7I3.

II. Gasic S, Bodenburg Y, Nagamani M, Green A, Urban RJ: Troglitazone inhibits progesterone production in porcine granulosa cells. Endocrinology 1998, 139:4962-4966.

12. Coffler MS, Patel K, Dahan MH, Yoo RY, Malcom PJ, Chang RJ: Enhanced granulosa cell responsiveness to follicle-stimulating hormone during insulin infusion in women with polycystic ovary syndrome treated with pioglitazone. J Clin Endocrinol Metab 2003, 88:5624-563I.

13. Chinetti G, Fruchart JC, Staels B: Peroxisome proliferator-activated receptors (PPARs): nuclear receptors at the crossroads between lipid metabolism and infiammation. Inflamm Res 2000, 49:497-505.

14. Sanchez-Hidalgo M, Martin AR, Villegas I, Alarcon C, Lastra De La: Rosiglitazone, an agonist of peroxisome proliferator-activated receptor gamma, reduces chronic colonic inflammation in rats. Biochem Pharmacol 2005, 69:1733-I744.

15. Moraes LA, Piqueras L, Bishop-Bailey D: Peroxisome proliferatoractivated receptors and inflammation. Pharmacol Ther 2006, I | 0:37|-385.

16. Martal J, Chêne N, Huynh L, Gharib-Hamrouche N, de la Llosa-Hermier MP: Cytokines and the corpus luteum. Contracept Fertil Sex 1994, 22:635-647.

17. Okuda K, Sakumoto R: Multiple roles of TNF super family members in corpus luteum function. Reprod Biol Endocrinol 2003, I:95.

18. Chen Q, Sun X, Li L, Gao X, Wu Y, Cheng L: Effects of ovarian high response on implantation and pregnancy outcome in fresh cycles and frozen embryo transfer cycles. Acta Obstet Gynecol Scand 2007, 86:849-854.

19. Seto-Young D, Avtanski D, Strizhevsky M, Parikh G, Patel P, Kaplun J, Holcomb K, Rosenwaks Z, Poretsky L: Interactions among peroxisome proliferator activated receptor-gamma, insulin signaling pathways, and steroidogenic acute regulatory protein in human ovarian cells. J Clin Endocrinol Metab 2007, 92:2232-2239.

20. Schaefer KL, Takahashi H, Morales VM, Harris G, Barton S, Osawa E, Nakajima A, Saubermann LJ: PPAR $\gamma$ inhibitors reduce tubulin protein levels by a PPAR $\gamma$, PPAR $\delta$ and proteasome-independent mechanism, resulting in cell cycle arrest, apoptosis and reduced metastasis of colorectal carcinoma cells. Int J Cancer 2007, I 20:702-7I3.

21. Seargent JM, Yates EA, Gill JH: GW9662, a potent antagonist of PPAR $\gamma$, inhibits growth of breast tumour cells and promotes the anticancer effects of the PPAR $\gamma$ agonist rosiglitazone, independently of PPAR $\gamma$ activation. Br J Pharmacol 2004, I43(8):933-7

22. Ricote M, Li AC, Willson TM, Kelly CJ, Glass CK: The peroxisome proliferator-activated receptors-gamma is a negative regulator of macrophage activation. Nature 1998, 39 1:79-82.

23. Minge CE, Ryan NK, Hoek KH Van Der, Robker RL, Norman RJ: Troglitazone regulates peroxisome proliferator-activated receptors and inducible nitric oxide synthase in murine ovarian macrophages. Biol Reprod 2006, 74: I53-160.

24. Zolti M, Meirom R, Shemesh M, Wollach D, Mashiach S, Shore L, Rafael ZB: Granulosa cells as a source and target organ for tumor necrosis factor-alpha. FEBS Lett 1990, 26 1:253-255.

25. Brannstrom M, Bonello N, Wang LJ, Norman RJ: Effects of tumour necrosis factor $\alpha$ (TNF $\alpha$ ) on ovulation in the rat ovary. Reprod Fertil Dev 1995, 7:67-73.

26. Darbon JM, Oury F, Laredo J, Bayard F: Tumor necrosis factor $\alpha$ inhibits follicle-stimulating hormone-induced differentiation in cultured rat granulosa cells. Biochem Biophys Res Commun 1989, 163:1038-1046.

27. Prange-Kiel J, Kreutzkamm C, Wehrenberg U, Rune GM: Role of tumor necrosis factor in preovulatory follicles of swine. Biol Reprod 2001, 65:928-935.

28. Drouineaud V, Sagot P, Garrido C, Logette E, Deckert V, Gambert P, Jimenez C, Staels B, Lagrost L, Masson D: Inhibition of progesterone production in human luteinized granulosa cells treated with LXR agonists. Mol Hum Reprod 2007, I3:373-379.

29. Lindeberg M, Carlström K, Ritvos O, Hovatta O: Gonadotrophin stimulation of non-luteinized granulosa cells increases steroid production and the expression of enzymes involved in estrogen and progesterone synthesis. Hum Reprod 2007, 22:401-406.

30. Sasson R, Amsterdam A: Stimulation of Apoptosis in Human Granulosa Cells from in Vitro Fertilization Patients and Its Prevention by Dexamethasone: Involvement of Cell Contact and Bcl-2 Expression. J Clin Endocrinol Metab 2002, 87:344I-345I.

31. Sasson R, Rimon E, Dantes A, Cohen T, Shinder V, Land-Bracha A, Amsterdam A: Gonadotrophin-induced gene regulation in human granulosa cells obtained from IVF patients. Modulation of steroidogenic genes, cytoskeletal genes and genes coding for apoptotic signalling and protein kinases. Mol Hum Reprod 2004, 10:299-3II.

\section{Publish with Bio Med Central and every scientist can read your work free of charge}

"BioMed Central will be the most significant development for disseminating the results of biomedical research in our lifetime. "

Sir Paul Nurse, Cancer Research UK

Your research papers will be:

- available free of charge to the entire biomedical community

- peer reviewed and published immediately upon acceptance

- cited in PubMed and archived on PubMed Central

- yours - you keep the copyright 